\title{
EFEK ANTIINFLAMASI EKSTRAK ETANOL DAUN KERSEN (Muntingia calabura L.) PADA MENCIT (Mus musculus)
}

\author{
Safriani Rahman, Aulia Wati, dan Eka Mega Asariningtyas \\ Fakultas Farmasi Universitas Muslim Indonesia \\ Email : safriani.rahman@umi.ac.id
}

\begin{abstract}
Leaf cherry (Muntingia Calabura L) empirically been used by the public as an anti-inflammatory drug. Cherry leaf contains flavonoids are thought to have antioxidant effects. This study has been tested antiinflammatory effect of ethanol extract of leaves of cherry (Muntingia Calabura L) in mice (Mus musculus). A total of 15 mice were divided into 5 groups of 3 animals. Group I (control) are given Na.CMC $1 \% \mathrm{w} / \mathrm{v}$, Group II, III, and IV (treatment) were given cherry leaf extract ethanol concentration of $1 \% \mathrm{w} / \mathrm{v}, 3 \% \mathrm{w} / \mathrm{v}$, and $5 \% \mathrm{w} / \mathrm{v}$, as well as groups $\mathrm{V}$ (comparison) given Diclofenac Sodium $0.195 \mathrm{mg} / 30 \mathrm{gBW}$. Before treatment all groups karagen induced with $1 \% \mathrm{w} / \mathrm{v}$ in intraplantar. Antiinflammatory effect was measured using pleytismometer. The results were analyzed statistically by one-way ANOVA method. The results showed that the ethanol extract of cherry leaf has anti-inflammatory effects and the concentration of $3 \%$ and $5 \% \mathrm{w} / \mathrm{v}$ has an effect no different to that diclofenac sodium.
\end{abstract}

Keywords: Muntingia Calabura L, antiinflammatory, ethanol extract.

\section{PENDAHULUAN}

Inflamasi merupakan suatu
respons protektif normal tubuh
terhadap luka jaringan yang
disebabkan oleh trauma fisik, zat kimia
yang merusak, atau zat-zat mikrobiologik. ${ }^{1}$ Inflamasi adalah usaha tubuh untuk menginaktivasi atau merusak organisme yang menyerang, menghilangkan zat iritan, dan mengatur derajat perbaikan jaringan. ${ }^{2}$ Inflamasi biasa diobati dengan menggunakan obat-obat antiinflamasi nonsteroid (OAINS), seperti natrium diklofenak. Pengobatan pasien dengan inflamasi mempunyai 2 tujuan utama, pertama, meringankan nyeri yang seringkali merupakan gejala awal yang terlihat dan keluhan utama yang terusmenerus dari pasien, dan kedua memperlambat dan membatasi proses perusakan jaringan. Pengobatan inflamasi seringkali berakibat meredanya rasa nyeri selama periode yang bermakna, ${ }^{3}$ namun sering timbul adanya efek samping seperti 
Efek antiinflamasi ekstrak etanol daun kersen (Muntingia calabura L.) pada mencit (Mus musculus)

kerusakan hati, gangguan saluran pencernaan, dan gangguan ginjal. Oleh karena itu, pengobatan tradisional merupakan alternative yang paling aman disamping itu memiliki efek samping yang lebih sedikit dari obat sintetik.

Salah satu tanaman yang secara empiris digunakan oleh masyarakat sebagai obat antiinflamasi adalah kersen (Muntingiaa calabura L). Hasil penelitian menunjukkan bahwa daun kersen mengandung senyawa flavonoid, triterpen, saponin, steroid, dan tanin yang menunjukkan aktifitas antioksidatif dan antimikroba. ${ }^{4}$ Ekstrak daun Kersen juga memiliki potensi dalam menurunkan kadar glukosa darah mencit pada dosis 0,3 $\mathrm{mL} / 30$ gBB. ${ }^{5}$ Berdasarkan uraian tersebut di atas, maka akan dilakukan penelitian tentang efek antiinflamasi ekstrak etanol daun kersen pada mencit untuk menambah data ilmiah dari daun kersen agar pemanfaatannya dapat dipertanggungjawabkan secara ilmiah pula.

\section{METODE KERJA}

Penyiapan Sampel dan Pengolahan

Sampel yang digunakan dalam penelitian adalah daun kersen (Muntingia calabura L.) yang berasal dari kota Makassar, Sulawesi Selatan.
Sampel yang telah dikumpulkan, dicuci bersih, dan dirajang atau dipotongpotong selanjutnya dikeringkan dengan cara diangin-anginkan tanpa terkena sinar matahari langsung.

\section{Pembuatan Bahan Penelitian}

Pembuatan ekstrak etanol $70 \%$ daun kersen (Muntingia calabura L.)

Ekstraksi sampel dilakukan dengan metode maserasi. Sebanyak $200 \mathrm{~g}$ sampel dimaserasi menggunakan etanol $70 \%$. Proses maserasi dilakukan selama $5 \times 24$ jam dengan pengadukan beberapa kali, kemudian disaring. Ampas yang diperoleh kemudian direndam kembali dengan etanol sampai menghasilkan larutan yang jernih. Hasil penyarian yang diperoleh dipekatkan dengan menggunakan rotavapor sampai diperoleh ekstrak etanol kental. ${ }^{6}$

Pembuatan suspensi karagen $1 \%$ b/v

$\begin{array}{llll}\text { Sebanyak } & 1 & \mathrm{~g} & \text { karagen }\end{array}$ ditambah larutan $\mathrm{NaCl} 0,9 \% 50 \mathrm{~mL}$, dihomogenkan kemudian dicukupkan volumenya hingga $100 \mathrm{~mL}$.

Pembuatan suspensi Na-CMC $1 \%$ b/v

$\begin{array}{lllll}\text { Sebanyak } & 1 & \mathrm{~g} & \mathrm{Na} & \mathrm{CMC}\end{array}$ dimasukkan sedikit demi sedikit ke dalam air suling panas (suhu $70^{\circ} \mathrm{C}$ ) sambil diaduk dengan menggunakan pengaduk elektrik hingga terbentuk 
Efek antiinflamasi ekstrak etanol daun kersen (Muntingia calabura L.) pada mencit (Mus musculus)

larutan koloidal yang homogen, kemudian dicukupkan volumenya hingga $100 \mathrm{~mL}$ dengan air suling. ${ }^{7}$

Pembuatan suspensi Na. Diklofenak 0,195 mg/30 gBB

Sebanyak 43,54 mg ditimbang. Kemudian disuspensikan dalam $\mathrm{Na}$. CMC 1\% kemudian diaduk hingga homogen, kemudian dicukupkan volumenya hingga $50 \mathrm{~mL}$.

Pembuatan suspensi ekstrak etanol daun kersen (Muntingia calabura L.)

Ekstrak etanol daun kersen yang diuji adalah ekstrak dengan konsentrasi $1 \% \mathrm{~b} / \mathrm{v}, 3 \% \mathrm{~b} / \mathrm{v}$ dan $5 \%$ b/v. Cara pembuatan suspensi ekstrak etanol daun kersen $1 \% \mathrm{~b} / \mathrm{v}$ adalah dengan menimbang sebanyak 1 gram ekstrak etanol daun kersen kemudian disuspensikan ke dalam $100 \mathrm{~mL} \mathrm{Na}$. CMC. Dilakukan hal yang sama untuk pembuatan ekstrak etanol daun kersen konsentrasi $3 \% \quad b / v$ dan $5 \% \quad b / v$ dengan menimbang ekstrak etanol daun kersen masing-masing 3 gram dan 5 gram kemudian disuspensikan ke dalam $100 \mathrm{~mL}$ Na. CMC.

\section{Pemilihan dan Penyediaan Hewan} Uji

Hewan uji yang digunakan adalah mencit (Mus musculus) jantan yang sehat dengan bobot badan 20 30 g. Mencit (Mus musculus) dipuasakan selama 8 jam sebelum perlakuan, kemudian ditimbang berat badannya.

\section{Perlakuan Terhadap Hewan Uji}

Sebanyak 15 ekor mencit jantan disiapkan, lalu dibagi dalam 5 kelompok masing-masing terdiri dari 3 ekor mencit. Kelompok I (kontrol) yang diberikan Na.CMC $1 \%$. Kelompok II, III, IV (perlakuan) yang diberikan ekstrak etanol daun kersen $1 \%$. $3 \%$, dan $5 \%$. Kelompok $\mathrm{V}$ (pembanding) diberikan suspense $\mathrm{Na}$. Diklofenak 0,195 mg/30 gBB. Sebelum perlakuan dilakukan pengukuran volume kaki sebagai volume kaki awal. Selanjutnya semua hewan uji diinduksi dengan karagen $1 \%$ sebanyak $0,1 \mathrm{~mL}$ secara intraplantar. Penentuan efek antiinflamasi dilakukan dengan mengukur volume edema telapak kaki mencit (Mus musculus). Pengukuran dilakukan dengan menggunakan pleytismometer. Pengukuran dilakukan pada menit 0 , $30,60,90$, dan 120. Hasil pengukuran volume edema dianalisis statistik menggunakan metode one way anova.

\section{HASIL DAN PEMBAHASAN}

Hasil pengujian efek antiinflamasi ekstrak etanol daun kersen (Muntingia calabura L.) pada mencit (Mus musculus) dapat dilihat pada tabel 1 di bawah ini : 
Efek antiinflamasi ekstrak etanol daun kersen (Muntingia calabura L.) pada mencit (Mus musculus)

Tabel 1. Data rata-rata hasil pengukuran kenaikan volume $(\mathrm{mm})$ pada pletismometer sebelum dan setelah waktu (menit) perlakuan

\begin{tabular}{|c|c|c|c|c|c|c|c|}
\hline \multirow{2}{*}{ PERLAKUAN } & \multirow{2}{*}{$\begin{array}{l}\text { SEBELUM } \\
\text { PERLAKUAN } \\
\pm \text { SD }\end{array}$} & \multirow{2}{*}{$\begin{array}{l}\text { INDUKSI } \\
\text { KARAGEN } \\
\pm \text { SD }\end{array}$} & \multicolumn{4}{|c|}{ SETELAH PERLAKUAN (MENIT) \pm SD } & \multirow{2}{*}{$\begin{array}{c}\% \\
\text { Penuruna } \\
\pm S D\end{array}$} \\
\hline & & & 30 & 60 & 90 & 120 & \\
\hline Na.CMC 1\% & $0.452 \pm 0.000$ & $\begin{array}{c}0.755 \pm \\
0.001\end{array}$ & $\begin{array}{c}0.755 \pm \\
0.001\end{array}$ & $\begin{array}{c}0.759 \pm \\
0.005\end{array}$ & $\begin{array}{c}0.756 \pm \\
0.001\end{array}$ & $\begin{array}{c}0.755 \pm \\
0.001\end{array}$ & $\begin{array}{c}0.088 \pm \\
0.076\end{array}$ \\
\hline EEDK $1 \%$ & $0.452 \pm 0.000$ & $\begin{array}{c}0.756 \pm \\
0.000\end{array}$ & $\begin{array}{c}0.708 \pm \\
0.016\end{array}$ & $\begin{array}{c}0.651 \pm \\
0.041\end{array}$ & $\begin{array}{c}0.589 \pm \\
0.055\end{array}$ & $\begin{array}{l}0.538 \\
\pm 0.11\end{array}$ & $\begin{array}{c}28.792 \pm \\
1.457\end{array}$ \\
\hline EEDK 3\% & $0.339 \pm 0.000$ & $\begin{array}{c}0.755 \pm \\
0.000\end{array}$ & $\begin{array}{c}0.662 \pm \\
0.012\end{array}$ & $\begin{array}{c}0.554 \pm \\
0.000\end{array}$ & $\begin{array}{c}0.460 \pm \\
0.011\end{array}$ & $\begin{array}{c}0.432 \pm \\
0.035\end{array}$ & $\begin{array}{c}42.737 \pm \\
1.457\end{array}$ \\
\hline EEDK 5\% & $0.452 \pm 0.001$ & $\begin{array}{c}0.756 \pm \\
0.001\end{array}$ & $\begin{array}{c}0.628 \pm \\
0.064\end{array}$ & $\begin{array}{c}0.498 \pm \\
0.076\end{array}$ & $\begin{array}{c}0.416 \pm \\
0.017\end{array}$ & $\begin{array}{c}0.389 \pm \\
0.032\end{array}$ & $\begin{array}{c}48.565 \pm \\
4.302\end{array}$ \\
\hline $\begin{array}{l}\text { Na. } \\
\text { diklofenak }\end{array}$ & $0.452 \pm 0.001$ & $\begin{array}{c}0.756 \pm \\
0.000\end{array}$ & $\begin{array}{c}0.589 \pm \\
0.057\end{array}$ & $\begin{array}{c}0.488 \pm \\
0.058\end{array}$ & $\begin{array}{c}0.436 \pm \\
0.016\end{array}$ & $\begin{array}{c}0.366 \pm \\
0.028\end{array}$ & $\begin{array}{c}51.543 \pm \\
3.751\end{array}$ \\
\hline
\end{tabular}

Keterangan : EEDK : ekstrak etanol daun kersen

Tabel 2. Analisis one way anova penurunan edema kelompok perlakuan

\begin{tabular}{lc}
\hline \multicolumn{1}{c}{ Kelompok } & $\begin{array}{c}\text { Nilai Signifikan } \\
(\mathbf{p})\end{array}$ \\
\hline $\mathrm{Na} . \mathrm{CMC} 1 \% \mathrm{~b} / \mathrm{v}$ & \\
EEDK $1 \% \mathrm{~b} / \mathrm{v}$ & \\
EEDK $3 \% \mathrm{~b} / \mathrm{v}$ & 0,000 \\
EEDK $5 \% \mathrm{~b} / \mathrm{v}$ & \\
$\mathrm{Na}$. Diklofenak & \\
\hline Ket $: \mathrm{p}<0,05$ = berbeda nyata &
\end{tabular}

Tabel 3. Uji Lanjutan Bonforenni Persen Penurunan Edema Kelompok Perlakuan

\begin{tabular}{|c|c|c|}
\hline Kelompok & Nilai Signifikan & Keterangan \\
\hline Na. CMC $1 \%$ b/v - EEDK $1 \%$ b/v & 0,000 & $\mathrm{BN}$ \\
\hline Na. CMC $1 \%$ b/v - EEDK $3 \%$ b/v & 0,000 & $\mathrm{BN}$ \\
\hline Na. CMC $1 \% \mathrm{~b} / \mathrm{v}-$ EEDK $5 \% \mathrm{~b} / \mathrm{v}$ & 0,000 & $\mathrm{BN}$ \\
\hline Na. CMC $1 \%$ b/v - Na. Diklofenak & 0,000 & $\mathrm{BN}$ \\
\hline EEDK $1 \% \mathrm{~b} / \mathrm{v}-\mathrm{EEDK} 3 \% \mathrm{~b} / \mathrm{v}$ & 0,005 & $\mathrm{BN}$ \\
\hline EEDK $1 \% \mathrm{~b} / \mathrm{v}-\mathrm{EEDK} 5 \% \mathrm{~b} / \mathrm{v}$ & 0,000 & $\mathrm{BN}$ \\
\hline EEDK $1 \% \mathrm{~b} / \mathrm{v}-\mathrm{Na}$. Diklofenak & 0,000 & $\mathrm{BN}$ \\
\hline EEDK $3 \% \mathrm{~b} / \mathrm{v}-$ EEDK $5 \% \mathrm{~b} / \mathrm{v}$ & 0,590 & TBN \\
\hline EEDK 3\% b/v - Na. Diklofenak & 0,092 & TBN \\
\hline EEDK 5\% b/v - Na. Diklofenak & 1,000 & TBN \\
\hline
\end{tabular}


Efek antiinflamasi ekstrak etanol daun kersen (Muntingia calabura L.) pada mencit (Mus musculus)

PEMBAHASAN

Efek antiinflamasi ekstrak etanol daun kersen (Muntingia calabura L.) ditentukan dengan mengukur penurunan volume edema kaki mencit (Mus musculus) jantan yang telah diinduksi dengan karagen 1\%. Efek antiinflamasi ekstrak etanol daun kersen (Muntingia calabura L.) ditentukan dengan mengukur penurunan volume edema kaki mencit (Mus musculus) jantan yang telah diinduksi dengan karagen 1\%. karagen memberikan respon inflamasi dengan cepat dan pembengkakannya lebih nyata sehingga mudah diamati. Pengukuran volume edema menggunakan pletismometer. Metode ini lebih sederhana, cepat dengan hasil pengukuran yang akurat.

Hasil penelitian penurunan volume edema kaki mencit, dapat dilihat pada tabel 1. Pada tabel tersebut terlihat bahwa semua kelompok memperlihatkan kenaikan volume kaki setelah diinduksi dengan karagen $1 \%$. Karagen bersifat netral yang hanya menyebabkan edema dan tidak menyebabkan kematian jaringan, selain itu karagen mudah diterima oleh fisiologis tubuh.

Untuk melihat efek dari ekstrak etanol daun kersen dalam menurunkan volume edema kaki mencit, maka diujikan pada hewan coba mencit. Hewan uji dibagi menjadi 5 kelompok yang terdiri dari : kelompok I (kontrol) yang diberikan Na.CMC 1\%, kelompok II, III, dan IV (perlakuan) yang diberikan ekstrak etanol daun kersen konsentrasi $1 \%$, $3 \%$, dan $5 \% \mathrm{~b} / \mathrm{v}$, dan kelompok $\mathrm{V}$ (pembanding) yang diberikan Na.diklofenal 0,195 mg/30 gBB. Sebelum perlakuan, semua kolompok diinduksi dengan karagen $1 \%$. Karagen bersifat netral yang hanya menyebabkan edema, dan tidak menyebabkan kematian jaringan, selain itu karagen mudah diterima oleh fisiologis tubuh. Pada tabel 1 terlihat bahwa semua kelompok memperlihatkan kenaikan volume edema setelah diinduksi karagen 1\% b/v. Kenaikan tersebut menunjukkan adanya respon inflamasi.

Perlakuan terhadap hewan uji dilakukan setelah induksi karagen, hal ini dilakukan untuk melihat efek penurunan volume edema setelah perlakuan. Pada tabel 1 terlihat bahwa semua kelompok memperlihatkan adanya penurunan volume edema kaki mencit, kecuali kelompok kontrol. Penurunan volume edema diduga terjadi karena adanya flavanoid yang terkandung dalam ekstrak etanol daun kersen. Mekanisme antiinflamasi dari 
Efek antiinflamasi ekstrak etanol daun kersen (Muntingia calabura L.) pada mencit (Mus musculus)

flavanoid melalui beberapa jalur yaitu dengan penghambatan aktivitas enzim COX dan lipooksigenase, penghambatan akumulasi leukosit, penghambatan degranulasi netrofil, penghambatan pelepasan histamine. Aktivitas inflamasi dari flavanoid dengan penghambatan COX dan lipooksigenase yang dapat menyebabkan penghambatan sintesis leukotrien dan prostaglandin. Penghambatan akumulasi leukosit selama proses inflamasi akan menyebabkan penurunan respon tubuh terhadap inflamasi.

Penghambatan akumulasi leukosit ini terjadi karena penghambatan COX sehingga tromboksan akan dihambat. Penghambatan degranulasi neutrofil akan menggangu pelepasan asam arakidonat oleh neutrofil. Penghambatan pelepasan histamine terjadi karena flavanoid dapat menghambat pelepasan histamine pada sel mast. ${ }^{8}$

$$
\text { Untuk melihat adanya }
$$
perbedaan antar perlakuan maka data rata-rata persen penurunan yang terlihat pada tabel 1 dianalisis dengan metode one way anova. Hasil analisis menunjukkan berbeda nyata $(p<0,05)$. Hal tersebut menunjukkan bahwa adanya perbedaan yang nyata antar perlakuan.
Untuk melihat perbedaan antar kelompok perlakuan, maka analisis dilanjutkan uji Lanjutan Bonforenni (data dapat dilihat pada tabel 3). Hasil analisis menunjukkan bahwa kelompok EEDK 3\% b/v terhadap kelompok EEDK 5\% b/v dan kelompok Natrium Diklofenak tidak berbeda nyata. Hal ini berarti bahwa kelompok EEDK 3\% b/v memiliki efek yang sama dengan kelompok EEDK $5 \%$ b/v dan Natrium Diklofenak dalam menurunkan volume edema kaki mencit.

\section{KESIMPULAN}

Ekstrak etanol daun kersen (Muntingia calabura L.) konsentrasi $3 \% \mathrm{~b} / \mathrm{v}$ dan $5 \% \mathrm{~b} / \mathrm{v}$ mempunyai potensi sebagai antiinflamasi dan tidak berbeda nyata terhadap kelompok Natrium Diklofenak sebagai pembanding.

\section{DAFTAR PUSTAKA}

1. Pringgoutomo S. Buku Ajar Patologi I (umum) (Edisi I). Jakarta : Penerbit Sagung Seto, 2002.

2. Champe PC \& Harvey RA.. Farmakologi Ulasan Bergambar. (Edisi II). Jakarta : Widya Medika, 2013.

3. Katzung BG. Farmakologi Dasar dan Klinik (Edisi VIII). Jakarta : Salemba Medika, 2002.

4. Zakaria et al. In Vitro Antimicrobial Activity of Muntingia calabura extracts and fractions (Online) (http 
Efek antiinflamasi ekstrak etanol daun kersen (Muntingia calabura L.) pada mencit (Mus musculus)

:///www.academicjournals.org, diakses 12 Januari 2012.

5. Selvia A, Suhadiyah, Johannes E \& Hasyim Z. Uji Efektivitas Ekstrak Daun Kersen (Muntingia calubura L) Terhadap Penurunan Kadar Glukosa Darah Pada Mencit (Mus musculus), 2016.

6. Direktoral Jenderal POM. Cara Pembuatan Simplisia. Departemen Kesehatan Republik Indonesia: Jakarta, 1986.
7. Kibbe $\mathrm{AH}$. Handbook of Pharmaceutical Excipients. (Third Edition). American Pharmaceutical Association. London : Washington and Pharmacetical Press., 2000.

8. Riansyah $Y$, Mulqie $L$ \& Choesrina.. Uji Aktivitas Ekstrak Etanol Daun Ubi jalar Ungu (Ipomoea batatas) Terhadap Tikus Wistar Jantan. (Online).

karyailmiah.unisba.ac.id/index.php/ farmasi/article/viewfile/2191/pdf. Akses 15 desember 2016 